\title{
The role of Anopheles arabiensis and Anopheles coustani in indoor and outdoor malaria transmission in Taveta District, Kenya
}

\author{
Joseph M Mwangangi ${ }^{1,2^{*}}$, Ephantus J Muturi ${ }^{3}$, Simon M Muriu' ${ }^{1}$, Joseph Nzovu' ${ }^{1}$, Janet T Midega ${ }^{1,4}$
} and Charles Mbogo ${ }^{1,2}$

\begin{abstract}
Background: The scaling up of malaria vector control efforts in Africa has resulted in changing the malaria vectorial systems across different ecological settings. In view of the ongoing trends in vector population dynamics, abundance, species composition and parasite infectiousness, there is a need to understand vector distribution and their contribution to malaria transmission to facilitate future planning of control strategies. We studied indoor and outdoor malaria transmission dynamics and vector population variability of Anopheles mosquitoes in Taveta district along the Kenyan Coast.
\end{abstract}

Methods: Anopheles mosquitoes were collected indoors and outdoors in 4 ecologically different villages using CDC light traps (both indoor and outdoor) and aspiration method (day resting indoors; DRI) methods. Mosquitoes were examined for infection with P. falciparum sporozoites and blood feeding preferences using enzyme linked immunosorbent assay (ELISA). The An. gambiae and An. funestus complexes were identified by PCR technique to determine the sibling species composition.

Results: A total of 4,004 Anopheles mosquitoes were collected consisting of 34.9\%\% ( $n=1,397)$ An. gambiae s.1., $28.1 \%(n=1,124)$ An. funestus s.l., $33.5 \%(n=1,340)$ An. coustani and 3.6\% $(n=143)$ An. pharoensis. A total of 14,654 culicine mosquitoes were collected, mainly $C x$. quinquefasciatus. Of the total Anopheles collected, 3,729 were tested for $P$. falciparum sporozoite infection. The sporozoite transmission was found to be occurring both indoors and outdoors. The overall sporozoite infectivity was $0.68 \%(n=2,486)$ indoors and $1.29 \%(n=1,243)$ outdoors. Indoor and outdoor sporozoite infectivity and the vectorial systems varied across the 4 ecological villages. Entomological inoculation rates for the 4 villages indicate that there was site-to-site variation. In the 4 villages, Mwarusa had the highest EIRs with An. arabiensis, An. funestus and An. coustani contributing to 23.91, 11.96 and 23.91 infectious bites per person per year ib/p/year respectively. In Kiwalwa and Njoro outdoor EIR was significantly higher than indoors.

Conclusions: This study shows that malaria transmission is occurring both indoors and outdoors. The main vectors are An. arabiensis, An. funestus and An. coustani indoors while An. coustani is playing a major role in outdoor transmission. Effective malaria control programmes, should therefore include tools that target both indoor and outdoor transmission.

\footnotetext{
* Correspondence: jmwangangi@kemri-wellcome.org

${ }^{1}$ Kenya Medical Research Institute (KEMRI), Centre for Geographic Medicine

Research Coast, P.O. Box 42880108, Kilifi, Kenya

${ }^{2}$ Malaria Public Health Department, KEMRI-Wellcome Trust Research Program,

P.O. Box 4364000100, Nairobi, Kenya

Full list of author information is available at the end of the article
}

\section{Biomed Central}

(c) 2013 Mwangangi et al.; licensee BioMed Central Ltd. This is an Open Access article distributed under the terms of the Creative Commons Attribution License (http://creativecommons.org/licenses/by/2.0), which permits unrestricted use, distribution, and reproduction in any medium, provided the original work is properly cited. 


\section{Background}

The malarial vectorial system in Africa is complex, comprising typically of Anopheles gambiae, An. arabiensis, and $A n$. funestus as the primary vectors and a number of complementally vectors including An. pharoensis, An. coustani and An. rivurolum [1-5]. While the ecology and behavior of the primary vectors is well documented [6-9], little is known about the ecology and behavior of complementally vectors. Previously considered unimportant, the role of these vectors in malaria transmission has increased over the years spurred by the widespread use of insecticide-treated bed nets that are selectively decimating An. gambiae and An. funestus populations while impacting little on complementally species and one primary vector An. arabiensis [10-12]. In order to maintain recent gains in malaria control and to proceed towards the intended target of malaria elimination, it will be important to develop strategies to interrupt malaria transmission by these vectors. This effort requires indepth knowledge of the ecology and behavior of these vectors.

To gauge levels of malaria control necessary to achieve meaningful public health improvements in Africa, it will be necessary to quantitatively define the extent to which site-specific entomological inoculation rates (EIRs) must be reduced to correspondingly reduce malaria prevalence [13-15]. A foundation of malaria vector control is that actions to decrease vector-host contact through methods including larval habitat modification, insecticide treatment of larval habitats, spraying insides of houses with residual insecticides, insecticide-treated bed nets, or the use of repellents will have correspondingly beneficial outcomes in terms of reduction in morbidity and mortality. Effective vector control measures decrease the incidence of malaria infections because there is a linear relationship between EIRs and malaria incidence [6,16-18].

In the 1940s-60s, indoor residual spraying (IRS) primarily using dichlorodiphenyltrichloroethane (DDT) reduced the incidence of malaria to zero, or to near zero, in regions where malaria was endemic $[19,20]$. The effectiveness of DDT against indoor resting mosquitoes led to the view that malaria could be eradicated through a combination of indoor residual spraying (IRS) and disease surveillance to detect and treat any remaining infections. In line with this notion, the Eighth World Health Assembly adopted the concept of malaria eradication resulting in the birth of the Global Eradication Program of Malaria in 1955 [21]. However, by the end of the 1960s it became evident that technical problems, such as resistance of mosquito vectors to insecticides such as DDT, $\mathrm{HCH}$, and dieldrin and resistance of malaria parasites to drugs, presented serious obstacles to the pursuit of eradication programs in many tropical countries [22-25]. In 1969 the World Health Organization recommended that although eradication of malaria should remain an ultimate goal, in countries where eradication does not appear to be feasible, malaria control operations may form a transitional stage [22]. During the second period, from 1965 to 1974, it became clear that the prospects for malaria control (let alone those for eradication) were related to the availability of a network of basic health services [22-25].

During the World Health Organization (WHO) malaria eradication program in 1955, the East African colonies established the Pare-Taveta malaria control scheme, on the Kenya-Tanzania border with its headquarters in Taveta. This program conducted a largescale trial in the Taveta sub-district of Kenya and the Pare district of Tanzania to determine whether malaria transmission could be interrupted through adoption of indoor residual spraying (IRS) [26,27]. During this expansive malaria control program, entomological and parasitological surveillance systems were used to monitor the changes in human malaria cases and the risk of malaria transmission. The IRS program not only reduced mortality due to malaria by half in all age groups but also eliminated An. funestus. In addition, there was a 7 -fold reduction in An. gambiae populations as well as a reduction in sporozoite rates to undetectable levels $[19,20,26]$. Despite this success, this program was discontinued in 1960s and as a result, An. funestus was reported 6 years later [28] and has recently been reported in this region [29].

In efforts to update the malarial vectorial system of these regions, field surveys were conducted to determine the relative abundance of malaria vectors and their role in malaria transmission in the Taveta area. Results of this research are particularly important in informing the policy makers in planning future interventions especially in agro-ecologic areas where there is a scale up of LLINs distribution.

\section{Methods \\ Study sites}

The study was conducted in Taveta, one of the 14 districts in the Coastal province, Kenya. The district lies between latitude $3^{\circ} 24^{\prime} 00^{\prime \prime} \mathrm{S}$ and longitude $37^{\circ} 41^{\prime} 00^{\prime \prime} \mathrm{E}$. Taveta district is about $109 \mathrm{~km}$ West from Voi town off the Nairobi-Mombasa road and is mainly inhabited by the Taveta ethnic group. The occupation of the people in this district is mainly casual waged labor, mixed farming, livestock and trade/business.

The area is a fairly plain terrain that generally slopes towards the south. The area is about $752 \mathrm{~m}$ above sea level. Rainfall in the district is inadequate, bimodal and very erratic. The mean annual rainfall ranges between $200 \mathrm{~mm}$ and $1,200 \mathrm{~mm}$. The long rains fall between March and May and the short rains occur between November and December. Temperature ranges from $21^{\circ} \mathrm{C}$ to $31^{\circ} \mathrm{C}$. The 
highest evaporation rate is experienced during the months of January to March. Agricultural activities in this area include horticulture (growing of tomatoes, kales, bananas), livestock farming (cattle, goat, sheep, poultry and bee keeping) and subsistence farming (growing of maize, beans, French beans and sugar) mainly through irrigation. Water for this purpose is derived from four rivers; Tsavo, Lumi, Njoro and Kitobo and spring water from the foot of Mt. Kilimanjaro.

Four villages representing distinct ecological zones were sampled for adult mosquitoes. These included Kiwalwa, Mwarusa, Kimundia and Njoro (Figure 1). Kiwalwa is a highly populated riverine ecosystem with clustered houses. Mwarusa village is a fairly flat and swampy area and river Lumi flows along the edge of the village. The households are sparsely distributed and the homesteads consist of three or more houses. Kimundia village is swampy and households are sparsely distributed and the homesteads consist of one or two houses. During the rainy season, some sections of this village are flooded and inaccessible. Njoro village is mainly in a semi-arid ecosystem and is typically dry and dusty during the dry season. The coordinates of mosquito collection stations in each village were taken using hand held GPS machines (Garmin International Inc., Olathe, KS) and used to develop base maps (ArcGIS 10).

The entomological sampling design was based on rainfall pattern and the strategy covered the long wet season (March and May), long dry season (June to October), short wet season (November and December) and short dry season (January to March). A comprehensive entomological sampling was done for two weeks in every season in 2011.

\section{Mosquito collection}

Mosquitoes were collected using standard Centre for Disease Control light traps (CDC, Atlanta, GA, USA) and manual aspiration techniques [30]. For each village, the collections were conducted in 10 randomly selected houses between 1800 and 0600 hrs. The selection criteria included the location and type of house (center, periphery, mud-walled, grass-thatched), presence or absence of aquatic habitats, and accessibility. One light trap was hung from the ceiling at the foot end of the bed and a second trap was positioned outdoors in the same house. The traps were removed in the morning and all cups containing mosquitoes were kept in the cool box for transportation to the laboratory for further processing.

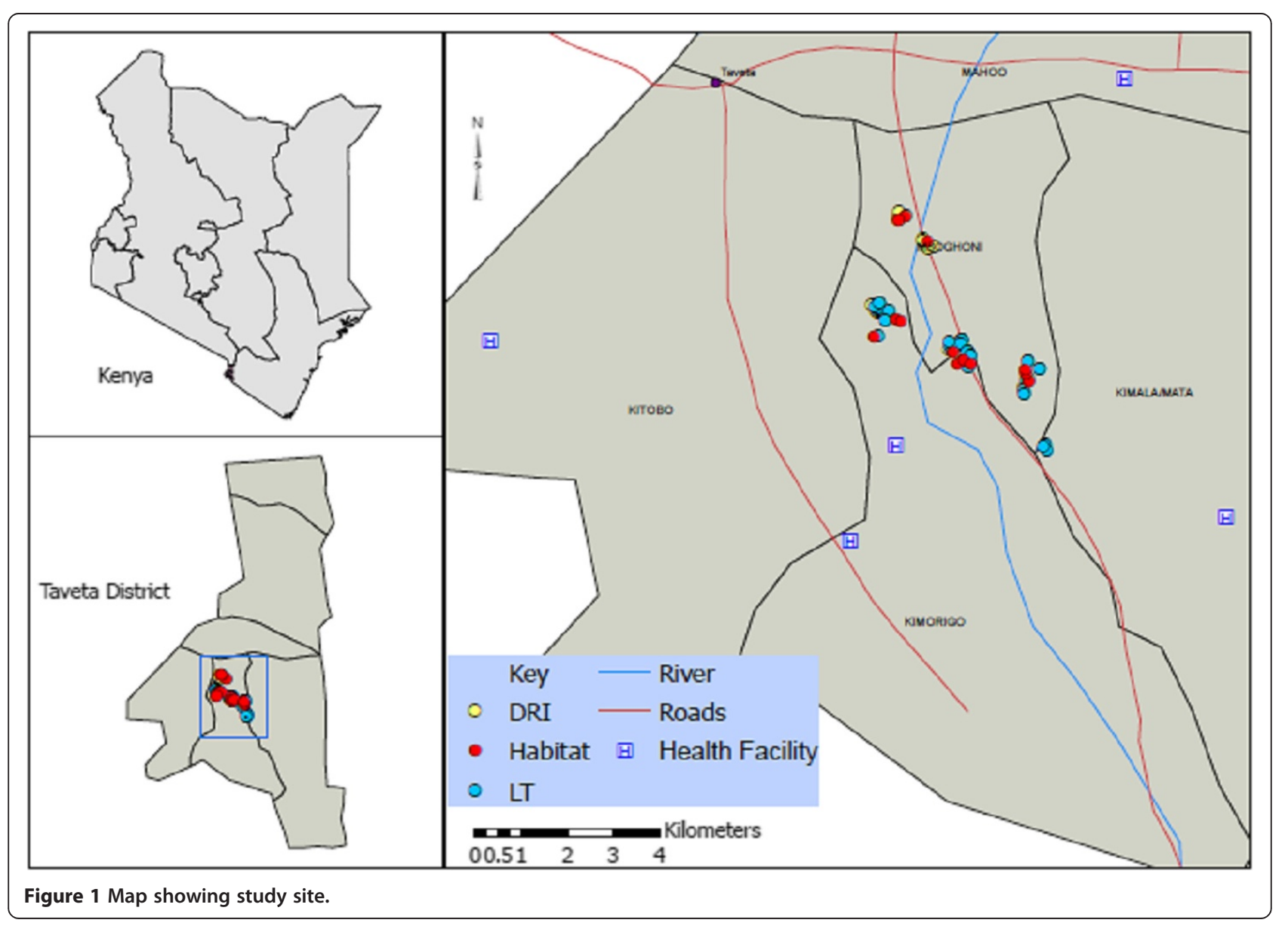


Ten different houses were selected in each village for manual mouth aspiration of indoor resting mosquitoes between 0600 and $1000 \mathrm{hrs}$ and transported to the laboratory for further processing.

\section{Mosquito identification and processing}

The mosquitoes were sorted to species and sex using taxonomic keys [31,32]. Female Anopheles mosquitoes were cut transversely between the thorax and abdomen. The head and thorax region was used for testing the sporozoite infectivity using Plasmodium falciparum sporozoite enzyme linked immunosorbent assay (ELISA) [33-35]. Blood-engorged females were also tested for blood meal sources by ELISA [36].

The wings and legs for An. gambiae complex were preserved in silica gel and further identified to sibling species by rDNA Polymerase Chain Reaction (PCR) [37,38]. Genomic DNA was extracted from the legs and wings of a proportion of females in the two complexes using the methods of Collins et al. [39,40] and amplified using specific diagnostic primers for An. gambiae s.s., An. arabiensis, and An. merus for An. gambiae complex [38,41].

\section{Data analysis}

Data was examined for normality and homogeneity of variance using Kolmogorov-Smirnov and Levene tests, respectively and log transformation was conducted to correct for deviation from normality. Repeated measures ANOVA with Greenhouse-Geisser correction was used to determine the effect of time, species, collection method and site on the mean number of adult mosquitoes collected.

\section{Entomologic indices}

Plasmodium falciparum sporozoite rates were calculated by expressing the number of $P$. falciparum positive mosquitoes as a percent of the total number of mosquitoes tested per species. The feeding preference was calculated by expressing the number of mosquitoes positive for each specific host as a proportion of the total mosquitoes tested. Human Blood Index ( $\mathrm{HBI}$ ) was calculated as the proportion of the mosquitoes positive for human blood divided by number tested successfully for blood meal analysis. The malaria transmission indices were determined by calculating the entomological inoculation rates (EIR). EIR was obtained for the day resting indoor aspiration by multiplying the human-biting rate by the proportion of sporozoite positive mosquitoes. The human-biting rates (the number of biting mosquitoes per human-night), was derived by dividing the total number of blood-fed and half-gravid mosquitoes caught by the number of persons sleeping in the house the night preceding the collection and multiplying the resulting value with HBI [6]. For the light trap collections, EIR was estimated including a conversion factor for Light trap catches vs. man biting catches of 1.605, as described earlier [42,43], without allowance for the number of occupants per room. The overall annual EIR for the LT, was calculated using standard methods, i.e. $1.605 \times$ (no. of sporozoite positive ELISA/ no. of mosquitoes tested)/(no. of mosquitoes collected/no. of catches) $\times 365$.

\section{Ethical considerations}

Verbal consent was obtained from the household head or their representative before commencing mosquito collection. These mosquito surveys were performed under human investigations protocols approved by the Ethical Review Board of Kenya Medical Research Institute (Nairobi, Kenya).

\section{Results}

Mosquito species composition and abundance

A total of 18,658 adult mosquitoes consisting of 1,397 An. gambiae s.l., 1,124 An. funestus, 1340 An. coustani, 143 An. pharoensis, and 14,654 Cx. quinquefasciatus were collected using the three techniques (Table 1). The relative abundance of the five mosquito species varied among study sites and collection methods (Table 1). In all the four study sites, $C x$. quiquefasciatus was the most abundant species in light trap collections both indoors and outdoors. The second most abundant species collected in light traps also varied by trap location and site. In Mwarusa and Njoro, respectively, An. gambiae s.l. and $A n$. funestus were the second most dominant species in both indoor and outdoor light trap collections. In Kimundia, An. coustani was the second most dominant species in outdoor light trap collections while An. gambiae s.l. was the second most dominant species in indoor light trap collections. In Kiwalwa, An. coustani was the second most dominant species in outdoor light traps while An. gambiae s.l. and An. constani were equally the second dominant species in indoor light traps (Table 1). In DRI collections, An. gambiae s.l. was the most abundant species in all study sites except Kiwalwa where An. funestus was the most dominant species (Table 1). In some sites but not others, An. gambiae s.l. and An. funestus were collected indoors rather than outdoors (Table 1). Conversely, there was a trend for collecting An. coustani more outdoors than indoors (Table 1).

Of the $459 A n$. gambiae s.l. samples that were identified to sibling species by PCR, $97.60 \%$ were characterized as $A n$. arabiensis and the rest were An. gambiae s.s $(2.40 \%)(\mathrm{n}=11)$.

\section{Mosquito density}

The mean number of $C x$. quinquefasciatus was $117.5 \pm$ 43.3 (mean \pm SE) and was significantly higher than $10.78 \pm$ 1.3, $8.1 \pm 1.0,7.2 \pm 2.0$, and $3.0 \pm 0.8$ for An. arabiensis, $A n$. funestus, An. coustani and An. phoroensis, respectively 
Table 1 The number of mosquitoes collected and their relative abundance from each village

\begin{tabular}{|c|c|c|c|c|c|c|}
\hline Village & Method & An. gambiae s.l. & An. funestus & An. coustani & An. pharoensis & Cx. quinquefasciatus \\
\hline \multirow[t]{4}{*}{ Kimundia } & DRI & $202(50.1)^{*}$ & $29(7.2)$ & $9(2.2)$ & $0(0.0)$ & $163(40.4)$ \\
\hline & LT Indoor & $187(6.3)$ & $48(1.6)$ & $62(2.1)$ & $65(2.2)$ & $2,587(87.7)$ \\
\hline & LT Outdoor & $20(0.9)$ & $36(1.6)$ & $346(15.4)$ & $9(0.4)$ & $1,836(81.7)$ \\
\hline & Sub-total & $409(7.3)$ & $113(2.0)$ & $417(7.4)$ & $74(1.3)$ & $4,586(81.9)$ \\
\hline \multirow[t]{4}{*}{ Kiwalwa } & DRI & $153(30.7)$ & $200(40.1)$ & $0(0.0)$ & $2(0.0)$ & $144(28.9)$ \\
\hline & LT Indoor & $235(14.8)$ & $366(23.2)$ & $231(14.5)$ & $22(1.4)$ & $735(46.3)$ \\
\hline & LT Outdoor & $76(1.0)$ & $130(1.7)$ & $526(7.0)$ & $7(0.1)$ & $6,800(90.2)$ \\
\hline & Sub-total & $464(4.8)$ & $696(7.2)$ & 757 (7.9) & $31(0.3)$ & 7,679 (79.8) \\
\hline \multirow[t]{4}{*}{ Mwarusa } & DRI & $169(54.7)$ & $33(10.7)$ & $2(0.6)$ & $1(0.3)$ & $104(33.7)$ \\
\hline & LT Indoor & $185(30.1)$ & $71(11.5)$ & $50(8.1)$ & $8(1.3)$ & $301(48.9)$ \\
\hline & LT Outdoor & $60(4.5)$ & $26(1.9)$ & $59(4.4)$ & $24(1.8)$ & $1,165(87.3)$ \\
\hline & Sub-total & $414(18.3)$ & $130(5.8)$ & $111(4.9)$ & $33(1.5)$ & $1,570(69.5)$ \\
\hline \multirow[t]{4}{*}{ Njoro } & DRI & $73(43.7)$ & $58(34.7)$ & $0(0.0)$ & $1(0.6)$ & $35(21.0)$ \\
\hline & LT Indoor & $18(5.3)$ & $50(14.7)$ & $15(4.4)$ & $2(0.6)$ & $254(74.9)$ \\
\hline & LT Outdoor & $19(2.8)$ & 77 (11.5) & $40(6.0)$ & $2(0.3)$ & $530(79.3)$ \\
\hline & Sub-total & $110(9.4)$ & $185(15.8)$ & $55(4.7)$ & $5(0.4)$ & $819(69.8)$ \\
\hline
\end{tabular}

*Parenthesis shows percentage.

$(\mathrm{F}=6.5, \mathrm{df}=4,603, \mathrm{P}<0.001)$ (Table 2). The mean number of An. pharoensis was also significantly lower than those of An. arabiensis and An. funestus. The mean number of adults collected varied by site, species, and collection method ( $\mathrm{F}=3.548$, df $=8,769,550.251)$. Regardless of the type of trap, Njoro had significantly lower numbers of $A n$. arabiensis compared to the other sites. Similarly for all trap types, Kiwalwa had a significantly higher number of $A n$. funestus compared to the other villages. In addition, the mean number of An. funestus collected with DRI and LT indoors was lowest in Kimundia, whereas for LT outdoors, the numbers were significantly lower in Mwarusa compared to the other villages. For $A n$. coustani the mean number of adults collected by DRI was significantly higher in Kimundia and Mwarusa compared to Kiwalwa and Njoro, whereas for LT indoors and outdoors, significantly

Table 2 Mean number of adult mosquitoes collected in the five villages using different collection methods

\begin{tabular}{|c|c|c|c|c|c|}
\hline \multirow[b]{2}{*}{ Method } & \multirow[b]{2}{*}{ Species } & \multicolumn{4}{|c|}{ Village } \\
\hline & & Kimundia & Kiwalwa & Mwarusa & Njoro \\
\hline \multirow[t]{5}{*}{$\overline{\mathrm{DRI}}$} & An. arabiensis & $17.4 \pm 6.1$ & $13.9 \pm 3.1$ & $16.9 \pm 4.3$ & $6.7 \pm 2.8$ \\
\hline & An. funestus & $1.3 \pm 0.6$ & $13.2 \pm 7.2$ & $3.0 \pm 1.5$ & $5.6 \pm 1.0$ \\
\hline & An. coustani & $0.8 \pm 0.6$ & $0.0 \pm 0.0$ & $0.8 \pm 0.2$ & $0.0 \pm 0.0$ \\
\hline & An. pharoensis & $0.0 \pm 0.0$ & $0.0 \pm 0.0$ & $0.0 \pm 0.0$ & $0.1 \pm 0.1$ \\
\hline & Cx. quinquefasciatus & $16.4 \pm 4.6$ & $13.1 \pm 2.7$ & $4.7 \pm 1.7$ & $4.0 \pm 1.5$ \\
\hline \multirow[t]{5}{*}{ LT indoor } & An. arabiensis & $18.7 \pm 8.1$ & $24.3 \pm 5.9$ & $18.1 \pm 6.1$ & $2.1 \pm 0.8$ \\
\hline & An. funestus & $3.0 \pm 1.1$ & $37.1 \pm 2.9$ & $8.1 \pm 0.2$ & $5.0 \pm 2.1$ \\
\hline & An. coustani & $6.2 \pm 1.7$ & $13.9 \pm 4.5$ & $4.0 \pm 1.3$ & $1.5 \pm 1.0$ \\
\hline & An. pharoensis & $6.5 \pm 3.2$ & $1.6 \pm 1.1$ & $0.8 \pm 0.5$ & $0.2 \pm 0.1$ \\
\hline & Cx. quinquefasciatus & $255.7 \pm 101.5$ & $75.5 \pm 15.8$ & $30.9 \pm 5.7$ & $24.5 \pm 5.3$ \\
\hline \multirow[t]{5}{*}{ LT outdoor } & An. arabiensis & $2.8 \pm 1.0$ & $6.8 \pm 1.9$ & $3.0 \pm 2.4$ & $1.2 \pm 0.6$ \\
\hline & An. funestus & $3.8 \pm 1.1$ & $13.8 \pm 2.9$ & $0.6 \pm 0.2$ & $7.2 \pm 2.1$ \\
\hline & An. coustani & $5.1 \pm 2.3$ & $43.7 \pm 16.8$ & $2.5 \pm 1.1$ & $3.4 \pm 1.4$ \\
\hline & An. pharoensis & $26.6 \pm 5.2$ & $0.6 \pm 0.3$ & $0.6 \pm 0.4$ & $0.0 \pm 0.0$ \\
\hline & Cx. quinquefasciatus & $791.8 \pm 477.6$ & $70.8 \pm 15.6$ & $84.7 \pm 40.8$ & $49.2 \pm 23.6$ \\
\hline
\end{tabular}


higher numbers were collected in Kiwalwa compared to the other villages. Finally, the mean number of $A n$. pharoensis collected in both LT indoors and LT outdoor traps was significantly higher in Kimundia compared to the other villages.

\section{The Plasmodium falciparum sporozoite rates and entomological inoculation rates in malaria vectors in Taveta District}

A total of 3,729 Anopheles mosquitoes were tested for $P$. falciparum sporozoite infection (Table 3). The sporozoite transmission was found occurr both indoors and outdoors. The overall indoor sporozoite infectivity rate was $0.68 \%$ ( $n=2,486)$ for mosquitoes collected indoors and $1.29 \%$ ( $\mathrm{n}=1,243$ ) for mosquitoes collected outdoors. The sporozoite infectivity rate was $0.66 \%(n=909)$ for mosquitoes collected using the aspiration method (Day Resting Indoors), $0.70 \%(\mathrm{n}=1,577)$ for mosquitoes collected using Light traps indoors and $1.29 \%$ for mosquitoes collected through Light trap outdoors. In the indoor sporozoite infectivity, Mwarusa had the highest sporozoite rates and 3 species namely $A n$. arabiensis, An. funestus and An. coustani were responsible for the transmission. In Kimundia, only $A n$. arabiensis was transmitting sporozoites while it was only An. funestus transmitting sporozite in Njoro. Sporozoite infected $A n$. coustani were collected indoors in Kiwalwa and Mwarusa.

For the outdoor transmission, An. coustani was the main vector and was found to be playing a key role in malaria transmission in the 4 villages. There was more outdoor sporozoite transmission in Njoro and in Kiwalwa. One way ANOVA showed that there was a significant difference in the sporozoite infectivity in the 4 villages $\left(\mathrm{F}_{(1,3)},=3.11, \mathrm{P}=0.025\right)$. None of the $A n$. pharoensis was found to be positive for sporozoites both indoors and outdoors.

Entomological inoculation rates for the 4 villages showed that there was site-to-site variation. In the 4 villages, Mwarusa had the highest EIRs and 3 vectors were mainly transmitting, which were An. arabiensis, An. funestus and An. coustani contributing to an estimated 23.91, 11.96 and $23.91 \mathrm{ib} / \mathrm{p} /$ year respectively. In Kiwalwa and Njoro outdoor EIR was significantly higher than indoors. An. arabiensis was the key vector contributing to the highest annual EIR (16.98 ib/p/year for LT traps) and $1.64 \mathrm{ib} / \mathrm{p} /$ year for DRI. Overall EIR for indoors using Light traps was 31.13 infective bites per person per year (ib/p/year) while using the aspiration method (DRI) this was was $1.05 \mathrm{ib} / \mathrm{p} /$ year. For the outdoor transmission, EIR was $56.81 \mathrm{ib} / \mathrm{p} /$ year.

Table 3 Plasmodium falciparum sporozoite transmission and Entomological Innoculation Rates (EIR) foci for Taveta District

\begin{tabular}{|c|c|c|c|c|c|c|c|}
\hline \multirow[b]{2}{*}{ Index } & \multirow[b]{2}{*}{ Method } & \multirow[b]{2}{*}{ Species } & \multicolumn{4}{|c|}{ Village } & \multirow[b]{2}{*}{ Total } \\
\hline & & & Kimundia & Kiwalwa & Mwarusa & Njoro & \\
\hline \multirow[t]{15}{*}{ Sporozoite rates } & DRI & An. coustani & 14 & 0 & 2 & 0 & 16 \\
\hline & & An. funestus & 29 & 200 & 33 & 46 & 308 \\
\hline & & An. arabiensis & 202 & 139 (0.72\%) & 167 (2.99\%) & 73 & $581(1.03 \%)$ \\
\hline & & An. pharoensis & 0 & 2 & 1 & 1 & 4 \\
\hline & & Total & 245 & 341 & $203(2.46 \%)$ & 120 & 909 (0.66\%) \\
\hline & LT Indoors & An. coustani & 67 & $231(0.43 \%)$ & $50(4.00 \%)$ & 3 & $351(0.85 \%)$ \\
\hline & & An. funestus & 48 & 366 & $71(1.41 \%)$ & $50(2.00 \%)$ & $535(0.37 \%)$ \\
\hline & & An. arabiensis & $167(1.80 \%)$ & $235(0.43 \%)$ & $185(1.08 \%)$ & 18 & 605 (0.99\%) \\
\hline & & An. pharoensis & 56 & 22 & 8 & 0 & 86 \\
\hline & & Total & $338(0.89 \%)$ & $854(0.23 \%)$ & 314 (1.59\%) & 70 (1.43\%) & $1,576(0.70 \%)$ \\
\hline & LT Outdoors & An. coustani & $346(0.29 \%)$ & $456(2.41 \%)$ & $59(1.69 \%)$ & $40(7.5 \%)$ & $901(1.78 \%)$ \\
\hline & & An. funestus & 36 & 76 & 11 & 77 & 200 \\
\hline & & An. arabiensis & 15 & 76 & 14 & 19 & 124 \\
\hline & & An. pharoensis & 9 & 7 & 0 & 2 & 18 \\
\hline & & Total & 406 (0.25\%) & 615 (1.79\%) & 84 (1.19\%) & $138(2.17 \%)$ & $1,243(1.29 \%)$ \\
\hline \multirow[t]{6}{*}{ Annual EIR } & DRI & An. arabiensis & 0.00 & 1.14 & 4.74 & 0.00 & 1.64 \\
\hline & LT Indoors & An. coustani & 0.00 & 11.72 & 23.91 & 0.00 & 8.49 \\
\hline & & An. funestus & 0.00 & 0.00 & 11.96 & 11.05 & 5.66 \\
\hline & & An. arabiensis & 31.95 & 11.72 & 23.91 & 0.00 & 16.98 \\
\hline & & Total & 31.95 & 23.43 & 59.78 & 11.05 & 31.13 \\
\hline & LT outdoors & An. coustani & 17.23 & 123.92 & 14.65 & 45.06 & 56.81 \\
\hline
\end{tabular}




\section{Discussion}

Our results show that indoor malaria transmission is mainly perpetuated by $A n$. arabiensis, An. funestus and $A n$. Coustani, while outdoor transmission is sustained by An. coustani. Traditionally, malaria transmission in much of Africa has been dominated by An. gambiae and An. Funestus, which primarily feed and rest indoors where they can be efficiently targeted with domestic insecticides [44-46]. There is growing evidence from across the continent that the widespread use of LLINs and IRS is driving vector species composition toward those with more flexible feeding and resting behaviors $[10,47,48]$. Anopheles coustani has been collected in several parts of Africa but very rarely has been found infected with $P$. falciparum $[1,49]$. Malaria control experts have undoubtedly continued to deliver interventions that tackle indoor transmission in Africa. However, our results support previous findings that considerable investment in methods that target mosquito populations outdoors is urgently needed to sustain existing levels of malaria control and to make further inroads towards malaria elimination [48,50,51]. Currently in Africa, there is no intervention that specifically targets outdoor biting mosquitoes; instead most malaria vector control policies in Africa are based on the use of LLINs, prompt diagnosis and treatments and malaria in pregnancy [52]. Scale up of LLINs to universal coverage coupled with larval habitat management strategies, stakeholder involvement and community engagement packaged in integrated vector management (IVM) strategies would be ideal to significantly reduce indoor and outdoor resting vectors [53-55]. The only currently operational tool that could provide additive benefit to LLINs is larviciding [56-59], which by killing larval mosquitoes in their aquatic habitats may be assumed to efficiently target both the endophilic and exophilic proportion of vector populations.

Five mosquito species were collected in the 4 villages namely, An. arabiensis, An. funestus, An. coustani, An. pharoensis and $C x$. quinquefasciatus. This implies that the inhabitants of the 4 villages in Taveta district are exposed to both infectious and nuisance biting. There was significant variation in the densities of mosquitoes by site, species, and collection method. Villages that were mainly carrying out agricultural activities, such as Kiwalwa and Kimundia had a significantly higher number of mosquitoes, while arid and semi-arid areas such as Njoro had fewer mosquitoes throughout the year. This shows clearly that mosquito production is a function of the availability of larval habitats [60,61], with more mosquitoes being found in areas with available water for agricultural activities.

In Kiwalwa and Njoro, outdoor entomological inoculation rate (EIR) was higher than indoor EIR. This result shows that the level of exposure to $P$. falciparuminfected mosquitoes is higher outdoors as compared to indoors. EIR assessments in these villages show that it is important while conducting malaria transmission studies to consider estimating in both indoor and outdoor environments. This is because as efforts are increased to reduce human-vector contact indoors, this may have an effect in increasing outdoor transmission. Further, estimation of EIR using CDC light traps was found to be better compared to using a manual aspiration technique, which captured indoor day resting mosquitoes. However, there is a need to come up with more studies to evaluate the existing mosquito sampling tools in the view of current vectorial shifts in behavior and in composition $[10,12,62]$. In this study CDC light traps were used for outdoor and indoor sampling since some earlier studies have shown that $\mathrm{CDC}$ light traps are effective for indoor collection of host seeking mosquitoes, with a catch that compares well with the standard human landing catch method [42,43]. This study has shown that there is outdoor transmission of malaria, there is need to enhance outdoor sampling and more sampling tools need to be evaluated to ensure outdoor collections are optimized.

In this study, CSP-ELISA, which is widely used to estimate the sporozoite index, was used to gauge the level of malaria transmission [6,63-69]. However, several studies have reported false positive results using CSP-ELISA [70-74]. To overcome some of challenges posed by CSPELISA, in particular, false positivity, it would be advantageous if future malaria transmission studies could be designed to detect sporozoites in mosquitoes using Plasmodium specific polymerase chain reaction (PCR) [74]. PCR should be able to detect very few sporozoites in a sample compared to ELISA, which requires several sporozoites.

\section{Conclusion}

In conclusion, this study shows that malaria transmission is occurring both indoors and outdoors. Indoor transmission is mainly due to An. arabiensis, $A n$. funestus and An. coustani inside houses while $A n$. coustani is playing a major role in outdoor transmission. For effective malaria control programs, efforts should be made to incorporate more tools that target both indoor and outdoor transmission.

\section{Competing interest}

The authors declare that they have no competing interest.

\section{Authors' contributions}

JMM, EJM, SMM, JN and JTM conducted all the field and laboratory work. CMM provided scientific guidance in data collection, analysis and manuscript preparation and planning, and implementation of day-to-day field activities and offered scientific guidance in data analysis and manuscript preparation. All authors actively contributed to the interpretation of the findings and development of the final manuscript and approved the final manuscript. 


\section{Acknowledgement}

We are grateful for the assistance of all scientific staff at the Kenya Medical research Institute, Center for Geographic Medicine Research-Coast, particularly Dr. Sabah Omar, Dr. Norbert Peshu and Professor Kevin Marsh We thank the technical and field staff for the collection and processing of the mosquitoes, particularly Festus Yaah, Shida David, Gabriel Nzai, Saidi Matano, Samuel Mukunde and Muckoi Fundi. We appreciate the effort made by Rosemary Wamae in data entry. This paper is published with the permission of the Director of the Kenya Medical Research Institute. This study was financially supported by Kenya Medical Research Institute through its Internal Research Grant (IRG) program (KEMRI/IRG/029).

\section{Author details}

'Kenya Medical Research Institute (KEMRI), Centre for Geographic Medicine Research Coast, P.O. Box 42880108, Kilifi, Kenya. ${ }^{2}$ Malaria Public Health Department, KEMRI-Wellcome Trust Research Program, P.O. Box 4364000100 , Nairobi, Kenya. ${ }^{3}$ lllinois Natural History Survey, University of Illinois, Urban-Champaign, USA. ${ }^{4}$ Department of Life Sciences, Imperial College London, South Kensington campus, London SW7 2AZ, UK.

\section{Received: 14 February 2013 Accepted: 17 April 2013}

Published: 20 April 2013

\section{References}

1. Bekele D, Belyhun Y, Petros B, Deressa W: Assessment of the effect of insecticide-treated nets and indoor residual spraying for malaria control in three rural kebeles of Adami Tulu District, South Central Ethiopia. Malaria J 2012, 11:127.

2. Gillies MT, Smith A: The effect of a residual house spraying campaign in East Africa on species balance in the Anopheles funestus group: the replacement of Anopheles funestus Giles by Anopheles rivulorum Leeson. Bull Entomol Res 1960, 51:243-252.

3. Hargreaves K, Koekemoer LL, Brooke BD, Hunt RH, Mthembu J, Coetzee M: Anopheles funestus resistant to pyrethroid insecticides in South Africa. Med Vet Entomol 2000, 14:181-189.

4. Kawada H, Dida GO, Sonye G, Njenga SM, Mwandawiro C, Minakawa N: Reconsideration of Anopheles rivulorum as a vector of Plasmodium falciparum in Western Kenya: some evidence from biting time, blood preference, sporozoite positive rate, and pyrethroid resistance. Parasit Vectors 2012, 5:230

5. Temu EA, Minjas JN, Coetzee M, Hunt RH, Shiff CJ: The role of four anopheline species (Diptera : Culicidae) in malaria transmission in coastal Tanzania. Trans R Soc Trop Med Hyg 1998, 92:152-158.

6. Mbogo CM, Mwangangi JM, Nzovu J, Gu W, Yan G, Gunter J, Swalm C, Keating J, Regens JL, Shililu Jl, et al: Spatial and temporal heterogeneity of Anopheles mosquitoes and Plasmodium falciparum transmission along the Kenyan coast. AmJTrop Med Hyg 2003, 68:734-742.

7. Mbogo CNM, Kabiru EW, Muiruri SK, Nzovu JM, Ouma JH, Githure Jl, Beier JC: Bloodfeeding behaviour of Anopheles gambiae s.l. and Anopheles funestus in Kilifi district, Kenya. J Am Mosa Control Assoc 1993, 9:225-227.

8. Muriu SM, Muturi EJ, Shililu Jl, Mbogo CM, Mwangangi JM, Jacob BG, Irungu LW, Mukabana RW, Githure JI, Novak RJ: Host choice and multiple blood feeding behaviour of malaria vectors and other anophelines in Mwea rice scheme. Kenya. Malaria J 2008, 7:43.

9. Mwangangi JM, Mbogo CM, Nzovu JG, Githure JI, Yan G, Beier JC: Blood meal analysis for anopheline mosquitoes sampled along the Kenyan coast. J Am Mosa Control Assoc 2003, 19:371-375.

10. Bayoh NM, Mathias DK, Odiere MR, Mutuku FM, Kamau L, Gimnig JE, Vulule JM, Hawley WA, Hamel MJ, Walker EW: Anopheles gambiae: historical population decline associated with regional distribution of insecticidetreated bed nets in western Nyanza Province, Kenya. Malaria J 2010, 9:62.

11. Derua YA, Alifrangis M, Hosea KM, Meyrowitsch DW, Magesa SM, Pedersen EM, Simonsen PE: Change in composition of the Anopheles gambiae complex and its possible implications for the transmission of malaria and lymphatic filariasis in north-eastern Tanzania. Malaria J 2012, 11:188

12. Meyrowitsch DW, Pedersen EM, Alifrangis M, Scheike TH, Malecela MN, Magesa SM, Derua YA, Rwegoshora RT, Michael E, Simonsen PE: Is the current decline in malaria burden in sub-Saharan Africa due to a decrease in vector population? Malaria J 2011, 10:188.

13. Alles HK, Mendis K, Carter R: Malaria mortality rates in South Asia and in Africa: implications for malaria control. Parasitol Today 1998, 14:369-375.
14. Greenwood B, Marsh K, Snow R: Why do some African children develop severe malaria? Parasitol Today 1991, 7:277-281.

15. Marsh K: Malaria - a neglected disease? Parasitology 1992, 104:S53-S69.

16. Beier JC, Killeen G, Githure Jl: Short report: entomologic inocululation rates and Plasmodium falciparum malaria prevalence in Africa. AmJTrop Med Hyg 1999, 61:109-113.

17. Beier JC, Oster CN, Onyango FK, Bales JD, Sharwood JA, Perkins PV, Chumo DK, Koech DK, Whitmire RE, Roberts CR, et al: Plasmodium falciparum incidences relative to entomologic inoculation rates at a site proposed for testing malaria vaccines in Western Kenya. AmJTrop Med Hyg 1994, 50:529-536.

18. Mbogo CNM, Snow RW, Khamala CPM, Kabiru EW, Ouma JH, Githure Jl, Marsh K, Beier JC: Relationships between Plasmodium falciparum transmission by vector populations and the incidence of severe disease at nine sites on the Kenyan coast. Am J Trop Hyg 1995, 52:201-206.

19. Curtis CF, Lines JD: Should DDT be banned by international treaty? Parasitol Today 2000, 16:119-121.

20. Curtis CF, Mnzava AEP: Comparison of house spraying and insecticide treated nets for malaria control. Bull World Health Organ 2000, 78:1389-1400.

21. WHO: Expert Committee on Malaria. Sixth Report. Geneva: World Health Organization; 1957

22. Bruce-Chwatt L: Malaria and its control: present situation and future prospects. Annu Rev Public Health 1987, 8:75-110.

23. Muturi EJ, Burgess P, Novak RJ: Malaria vector management: where have we come from and where are we headed? Am JTrop Med Hyg 2008, 78:536-537.

24. Bruce-Chwatt $\mathrm{L}$ : Lessons learned from applied field research activities in Africa during the malaria eradication era. Bull World Health Organ 1984, 62:19-29.

25. Najera J: Malaria control: achievements, problems, and strategies. Parasitologia 2001, 43:1-89.

26. East African Institute of Malaria and Vector-Borne Diseases: Report on the Pare-Taveta Malaria Scheme 1954-59. Dares Salaam: East Africa High Commission; 1960

27. Sama W, Killeen G, Smith T: Estimating the duration of Plasmodium falciparum infection from trials of indoor residual spraying. AmJTrop Med Hyg 2004, 70:625-634.

28. Smith A: Malaria in the Taveta area of Kenya and Tanganyika. II. Entomological findings three years after the spraying period. East Afr Med J 1962, 39:553-564.

29. Kamau L, Munyekenye GO, Koekemoer LL, Hunt RH, Coetzee M: A survey of the Anopheles funestus (Diptera: Culicidae) Group of mosquitoes from 10 sites in Kenya with special emphasis on population genetic structure based on chromosomal inversion karyotypes. J Med Entomol 2003, 40:664-671.

30. WHO: Manual on practical entomology in Malaria. Part II. Methods and techniques. Geneva: World Health Organization Offset Publication; 1975:No. 13

31. Edwards F: Mosquitoes of the Ethiopian region. III. Culicine adults and pupae. London: British Museum (Nat Hist); 1941.

32. Gillies MT: Anopheline mosquitoes: vector behaviour and bionomics. In Malaria: principles and practice of malariology. Edited by Wernsdorfer WH, McGregor I. Edinburgh: Churchill Livingstone; 1988:999-1090.

33. Beier JC, Perkins PV, Wirtz RA, Whitmire RE, Mugambi M, Hockmeyer WT: Field evaluation of an enzyme-linked immunosorbent assay (ELISA) for Plasmodium falciparum sporozoite detection in anopheline mosquitoes from Kenya. AmJTrop Med Hyg 1987, 36:459-468.

34. Wirtz RA, Burkot TR: Detection of malarial parasites in mosquitoes. Adv Dis Vect Res 1991, 8:77-106.

35. Wirtz RA, Zavala F, Charoenvit Y, Campbell GH, Burkot TR, Schneider I, Esser KM, Beaudoin RL, Andre RG: Comperative testing of Plasmodium falciparum Circumsporozoite antibody. Bull World Health Organization 1987, 65:39-45.

36. Beier JC, Perkins PV, Wirtz RA, Koros J, Diggs D, Gargan TP II, Koech DK: Blood meal identification by direct Enzyme-linked immunosorbent assay (ELISA), tested on Anopheles (Diptera : Culicidae) in Kenya. J Med Entomol 1988, 25:9-16

37. Koekemoer LL, Kamau L, Hunt RH, Coetzee M: A cocktail polymerase chain reaction (PCR) assay to identify the Anopheles funestus (Diptera: Culicidae) group. AmJTrop Med Hyg 2002, 6:78-83.

38. Scott JA, Brodgon WG, Collins FH: Identification of single specimens of Anopheles gambiae complex by Polymerase chain reaction. AmJTrop Med Hyg 1993, 49:520-529. 
39. Collins FH, Mehaffey PC, Rasmussen MO, AD B-B, Odera JS, Finnerty V: Comparison of DNA-Probe and Isoenzyme methods for differentiating Anopheles gambiae and Anopheles arabiensis (Diptera: culicidae). J Med Entomol 1988, 25:6-20.

40. Collins FH, Petrarca V, Mpofu S, Brandling-Benneth AD, Were JB, Rasmusssen $\mathrm{MO}$, Finerty V: Comparison of DNA-Probe and cytogenetic methods for identifying field collected Anopheles gambiae complex mosquitoes. AmJTrop Med Hyg 1988, 39:545-550.

41. Paskewitz SM, Collins FH: Use of the polymerase chain reaction to identify mosquito species of the Anopheles gambiae complex. Med Vet Entomol 1990, 4:367-373

42. Lines JD, Curtis CF, Wilkes TJ, Njunwa KJ: Monitoring human-biting mosquitoes (Diptera : Culicidae) in Tanzania with light traps hung beside mosquito nets. Bull World Health Organization 1991, 81:77-84.

43. Drakeley C, Schellenberg D, Kihonda J, Sousa CA, Arez AP, Lopes D, Lines J, Mshinda $\mathrm{H}$, Lengeler $\mathrm{C}$, Armstrong Schellenberg J, et al: An estimation of the entomological inoculation rate for Ifakara: a semi-urban area in a region of intense malaria transmission in Tanzania. Trop Med Int Health 2003, 8:767-774

44. Gillies MT, Coetzee M: A supplement to anophelinae of Africa south of Sahara (Afro-tropical region). Publication of the South Africa Institute of Medical Research 1987, 55:1-143.

45. Gillies MT, De Meillon B: The Anophelinae of Africa South of the Sahara, 2nd Edition. Publication of the South Africa Institute of Medical Research 1968, 54:12-36.

46. White GB: Anopheles gambiae complex and disease transmission in Africa. Trans R Soc Trop Med Hyg 1974, 68:278-301.

47. Geissbühler Y, Chaki P, Emidi B, Govella NJ, Shirima R, Mayagaya V, Mtasiwa D, Mshinda H, Fillinger U, Lindsay SW, Kannady SW, Caldas de Castro M, Tanner M, Killeen GF, et al: Interdependence of domestic malaria prevention measures and mosquito-human interactions in urban Dar es Salaam, Tanzania. Malaria J 2007, 6:126.

48. Govella NJ, Ferguson $\mathrm{H}$ : Why use of interventions targeting outdoor biting mosquitoes will be necessary to achieve malaria elimination. Front Physiol 2012, 3:199

49. Mwangangi JM, Midega J, Kahindi S, Njoroge L, Nzovu J, Githure J, Mbogo CM, Beier JC: Mosquito species abundance and diversity in Malindi, Kenya and their potential implication in pathogen transmission. Parasitol Res 2012, 110:61-71.

50. Ferguson HM, Dornhaus A, Beeche A, Borgemeister C, Gottlieb M, Mulla MS, Gimnig JE, Fish D, Killeen GF: Ecology: a prerequisite for malaria elimination and eradication. PLOS Med 2010, 7:e1000303.

51. Griffin JT, Hollingsworth TD, Okell LC, Churcher TS, White M, Hinsley W, Bousema T, Drakeley CJ, Ferguson NM, Basanez M, Ghani AC: Reducing Plasmodium falciparum malaria transmission in Africa: a model-based evaluation of intervention strategie. PLoS Med 2010, 7:e1000324

52. WHO/UNICEF: The African malaria report, WHO/CDS/ MAL/ 2003. Geneva: World Health Organization; 2003:1093.

53. Beier JC, Keating J, Githure JG, Macdonald MB, Impoinvil DE, Novak RJ: Integrated vector management for malaria control. Malaria J 2008, 7(Suppl 1):S4

54. WHO: Global Strategic Framework for Integrated Vector Management. Document WHO/CDS/CPE/PVC/2004.10. Geneva: World Health Organization; 2004.

55. WHO: Handbook for Integrated Vector Management (IVM). Geneva: WHO Press; 2012. WHO/HTM/NTD/NEM/2012.3.

56. Fillinger $U$, Knols BGJ, Becker N: Efficacy and efficiency of new Bacillus thuringiensis var. israelensis and Bacillus sphaericus formulations against Afrotropical anophelines in Western Kenya. Trop Med Int Health 2003, 8:37-47.

57. Fillinger $U$, Lindsay S: Suppression of exposure to malaria vectors by an order of magnitude using microbial larvicides in rural Kenya. Trop Med Int Health 2006, 11:1629-1642.

58. Killeen G, Fillinger U, Kiche I, Gouagna L, Knols B: Eradication of Anopheles gambiae from Brazil: lessons for malaria control in Africa. Lancet Infect Dis 2002, 2:618-627.

59. Killeen GF, McKenzie FE, Foy BD, Schieffelin C, Billingsley PF, Beier JC: The potential impact of integrated malaria transmission control on entomologic inoculation rate in highly endemic areas. Am J Med Hyg 2000, 62:545-551.

60. Muturi EJ, Shililu J, Jacob B, Gu W, Githure J, Novak R: Mosquito species diversity and abundance in relation to land use in a riceland agroecosystem in Mwea, Kenya. J Vector Ecol 2006, 31:129-137.
61. Mwangangi JM, Shililu J, Muturi EJ, Muriu S, Jacob B, Kabiru EW, Mbogo CM, Githure J, Novak RJ: Anopheles larval abundance and diversity in three rice agro-village complexes Mwea irrigation scheme, central Kenya. Malaria J 2010, 9:228

62. Brasseur P, Badiane M, Cisse M, Agnamey P, Vaillant MT, Olliaro PL: Changing patterns of malaria during 1996-2010 in an area of moderate transmission in Southern Senegal. Malaria J 2011, 10:203.

63. Beier JC, Asiago CM, Onyango FK, Koros JK: ELISA absorbance cut-off method affects malaria sporozoite rate determination in wild Afrotropical Anopheles. Med Veterinary Entomol 1988, 2:259-264.

64. Beier JC, Perkins PV, Koros JK, Onyango FK, Gargan TP, Wirtz RA, Koech DK, Roberts CR: Malaria sporozoites detection by dissection and ELISA to assess infectivity of Afrotropical Anopheles (Diptera : Culicidae). J Med Entomol 1990, 27:377-384.

65. Burkot TR, Graves PM, Cattan JA, Wirtz RA, Gibson FD: The efficiency of sporozoite transmission in the human malarias, Plasmodium falciparum and P. vivax. Bull World Health Organ 1987, 65:375-380.

66. Burkot TR, Williams JL, Schneider I: Identification of Plasmodium falciparum-infected mosquitoes by a double antibody enzyme-linked immunosorbent assay. AmJTrop Med Hyg 1984, 33:783-788.

67. Burkot TR, Wirtz R: Immunoassays of malaria sporozoite in mosquitoes. Parasitol Today 1986, 2:155-157.

68. Mbogo CM, Snow RW, Kabiru E, Ouma JH, Githure Jl, Marsh K, Beier J: Low-level Plasmodium falciparum transmission and the incidence of severe malaria infection on the Kenyan Coast. Am J Trop Med 1993, 49:245-253.

69. Mwangangi JM, Mbogo CM, Orindi BO, Muturi EJ, Midega JT, Nzovu J, Gatakaa H, Githure J, Borgemeister C, Keating J, Beier JC: Shifts in malaria vector species composition and transmission dynamics along the Kenyan coast over the past 20 years. Malaria J 2013, 12:13.

70. Koekemoer LL, Rankoe EM, la Grange JP, Govere J, Coetzee M: False detection of Plasmodium falciparum sporozoites in Anopheles marshallii group mosquitoes. J Am Mosq Control Assoc 2001, 17:160-165.

71. Lochouarn L, Fontenille D: ELISA detection of malaria sporozoites: falsepositive results in Anopheles gambiae s.l. associated with bovine bloodmeals. Trans R Soc Trop Med Hyg 1999, 93:101-102.

72. Mouatcho JC, Hargreaves K, Koekemoer LL, Brooke BD, Oliver SV, Hunt RH, Coetzee M: Indoor collections of the Anopheles funestus group (Diptera: Culicidae) in sprayed houses in northern KwaZulu-Natal, South Africa. Malaria J 2007, 6:30.

73. Somboon P, Morakote N, Koottathep S, Trisanarom U: Detection of sporozoites of Plasmodium vivax and Plasmodium falciparum in mosquitoes by ELISA: false positivity associated with bovine and swine blood. Trans R Soc Trop Med Hyg 1993, 87:322-324.

74. Durnez L, Van Bortel W, Denis L, Roelants P, Veracx A, Trung HD, Sochantha T, Coosemans M: False positive circumsporozoite protein ELISA: a challenge for the estimation of the entomological inoculation rate of malaria and for vector incrimination. Malaria J 2011, 10:195.

\section{doi:10.1186/1756-3305-6-114}

Cite this article as: Mwangangi et al: The role of Anopheles arabiensis and Anopheles coustani in indoor and outdoor malaria transmission in Taveta District, Kenya. Parasites \& Vectors 2013 6:114

\section{Submit your next manuscript to BioMed Central and take full advantage of:}

- Convenient online submission

- Thorough peer review

- No space constraints or color figure charges

- Immediate publication on acceptance

- Inclusion in PubMed, CAS, Scopus and Google Scholar

- Research which is freely available for redistribution 